\title{
MORPHOLOGY AND DYNAMICS OF IGE RISES
}

\author{
By P. J. Martin and T. J. O. Sanderson \\ (British Antarctic Survey, Natural Environment Research Council, Madingley Road, \\ Cambridge $\mathrm{CB}_{3}$ oET, England)
}

\begin{abstract}
Profile surveys are presented of four ice rises on the east coast of the Antarctic Peninsula. On Butler Island velocity measurements were also made. The ice rises behave as miniature ice caps frozen to flat horizontal bedrock and provide a simple system for the study of laws of ice flow. Deformation is principally by shear through the ice mass. Velocity measurements provide a value of $n=3.13 \pm 0.52$ for the flow law $\dot{\epsilon}=(\tau / B)^{n}$. Each ice rise is bounded on one side by ice shelf and on the other side by open sea. Towards open sea the profiles are found to agree well with steady-state theoretical profiles and they supply a value of $B=(1.25 \pm 0.2 \mathrm{I}) \times 10^{8} \mathrm{~N} \mathrm{~m}^{-2} \mathrm{~s}^{1}$ for temperature $-13.5^{\circ} \mathrm{C}$ and stress range $0.5^{-1.3}$ bar. Towards ice shelf the profiles are elongated and they deviate from the theoretical profile. This may be due to compressive stress in the ice shelf causing migration of the grounding line down sloping bedrock. No significantly anomalous behaviour is found in the summit region.

RÉsumé. Morphologie et dynamique de monticules de glace. On présente des profils réalisés sur quatre monticules de glace sur la côte Est de la Péninsule Antarctique. On a également fait des mesures de vitesse sur Butler Island. Les monticules de glace se comportent comme des calottes de glace en miniature gelée jusqu'au lit plan horizontal et procure un cas simple pour l'étude des lois d'écoulement de la glace. La déformation est principalement due à un cisaillement dans la masse de glace. Les mesures de vitesse donnent une valeur de $n=3, \mathrm{r} 3 \pm 0,5^{2}$ pour la loi d'écoulement $\epsilon=(\tau / B)^{n}$. Chaque monticule de glace est entouré d'un côte par la zone englacée et de l'autre par la mer libre. Vers la mer libre les profils trouvés concordent bien avec le profil d'équilibre théorique et font attribuer à $B$ une valeur $B=(\mathrm{I}, 25 \pm 0,2 \mathrm{I}) \times 10^{8} \mathrm{~N} \mathrm{~m}^{-2} \mathrm{~s}^{\frac{1}{3}}$ pour une température de $-13,5^{\circ} \mathrm{C}$ et une gamme de contrainte de 0,5 à 1,3 bar. Du côté de la zone englacée, les profils sont allongés et déviés du profil théorique. Ceci peut être dû aux efforts de compression dans la glace entrainant la migration de la ligne de décollement vers le bas de la pentè du lit rocheux. On n'a pas trouvé de comportement significativement anormal dans la région sommitale.

Zusammenfassung. Morphologie und Dynamik von Eisaufwölbungen. Für 4 Eisaufwölbungen an der Ostküste der antarktischen Halbinsel werden Profilvermessungen wiedergegeben. Am Butler Island liegen auch Geschwindigkeitsmessungen vor. Die Eisaufwölbungen verhalten sich wie Miniatur-Eisschilde, angefroren auf ebenem, horizontalem Untergrund, und bilden ein einfache System zum Studium der Fliessgesetze des Eises. Deformation ist in erster Linie eine Folge von Scherung durch die Eismasse. Geschwindigkeitsmessungen ergeben einen Wert von $n=3,13 \pm 0,5^{2}$ für das Fliessgesetz $\dot{\epsilon}=(\tau / B)^{n}$. Jede Aufwölbung ist auf der einen Seite vom Schelfeis, auf der anderen vom offenen Meer begrenzt. Gegen das offene Meer zeigen die Profile gute Übereinstimmung mit theoretisch stationären Profilen; sie liefern einen Wert für $B$ von $(\mathrm{r}, 25 \pm 0,2 \mathrm{I}) \times 10^{8} \mathrm{~N} \mathrm{~m}^{-2} \mathrm{~s}^{\dagger}$ bei einer Temperatur von $-13,55^{\circ} \mathrm{C}$ und einem Spannungsbereich von $0,5^{-1,3}$ bar. Gegen das Schelfeis sind die Profile verflacht und weichen vom theoretischen Profil ab. Dies dürfte von der Druckspannung im Schelfeis herrühren, die eine Tieferlegung der Aufsitzlinie bei geneigtem Untergrund bewirkt. Im Scheitelgebiet ist kein wesentlich anormales Verhalten festzustellen.
\end{abstract}

\section{INTRODUCTION}

When an area of floating ice shelf is halted by grounding, accumulation over the pinned area may lead to the formation of a dome-shaped ice rise. The flow in such a system is approximately radial and largely independent of the surrounding ice shelf. Under constant climatic conditions an equilibrium should be reached between gains due to accumulation and losses due to outward flow. The surface profile of the ice rise in equilibrium is a consequence of the flow properties of ice and the geometry of the bed on which it rests. Many ice rises rest on nearly horizontal beds, either because the ice shelf has grounded on a shoal or because any irregularities have been eroded by the ice shelf. Many are of a convenient size for experiment, and conditions of mean annual temperature, mean density, and accumulation are expected to vary little over their extent. Ice rises are therefore particularly well suited to the study of ice deformation under quite simple conditions. Here we describe measurements carried out on four ice rises located on Larsen Ice Shelf, which stretches along the east coast of the Antarctic Peninsula.

Other studies have been made on similar features in the Antarctic. Surface and bedrock profiles have been measured for Drygalski Island (Kapitsa, I958; Savel'yev, I96I), an isolated 
island some $\mathrm{i} 8 \mathrm{~km}$ long and 4I $5 \mathrm{~m}$ thick, and an extensive survey has been made of Roosevelt Island (Bentley and Giovinetto, I962; Clapp, I965), a very large ice rise on the Ross Ice Shelf, of size $120 \times 70 \mathrm{~km}^{2}$ and thickness some $750 \mathrm{~m}$. Budd ( 1969 ) has studied the rheology of ice using data from Law Dome, a large dome-shaped promontory attached to the Antarctic ice sheet, but the present study is the first to investigate the flow of ice in small Antarctic ice rises.

\section{BASIC DESGRIPTION}

The ice rises studied are shown in Figure I: Gipps Ice Rise $\left(68^{\circ} 45^{\prime} \mathrm{S} ., 60^{\circ} \mathrm{o5}^{\prime} \mathrm{W}\right.$.), Ewing Island $\left(69^{\circ} 5^{8^{\prime}} \mathrm{S} ., 6 \mathrm{r}^{\circ} 25^{\prime} \mathrm{W}\right.$.), Dolleman Island $\left(70^{\circ} 35^{\prime} \mathrm{S} ., 60^{\circ} 50^{\prime} \mathrm{W}\right.$.), and Butler Island $\left(72^{\circ} \mathrm{r} 3^{\prime} \mathrm{S} ., 60^{\circ} 50^{\prime} \mathrm{W}\right.$.). They are roughly elliptical in plan, with diameters between 5 and $20 \mathrm{~km}$ and ratios of major to minor axis of about $\mathrm{I} .5$. They are between 280 and $460 \mathrm{~m}$ thick. Table I summarizes data on their dimensions.

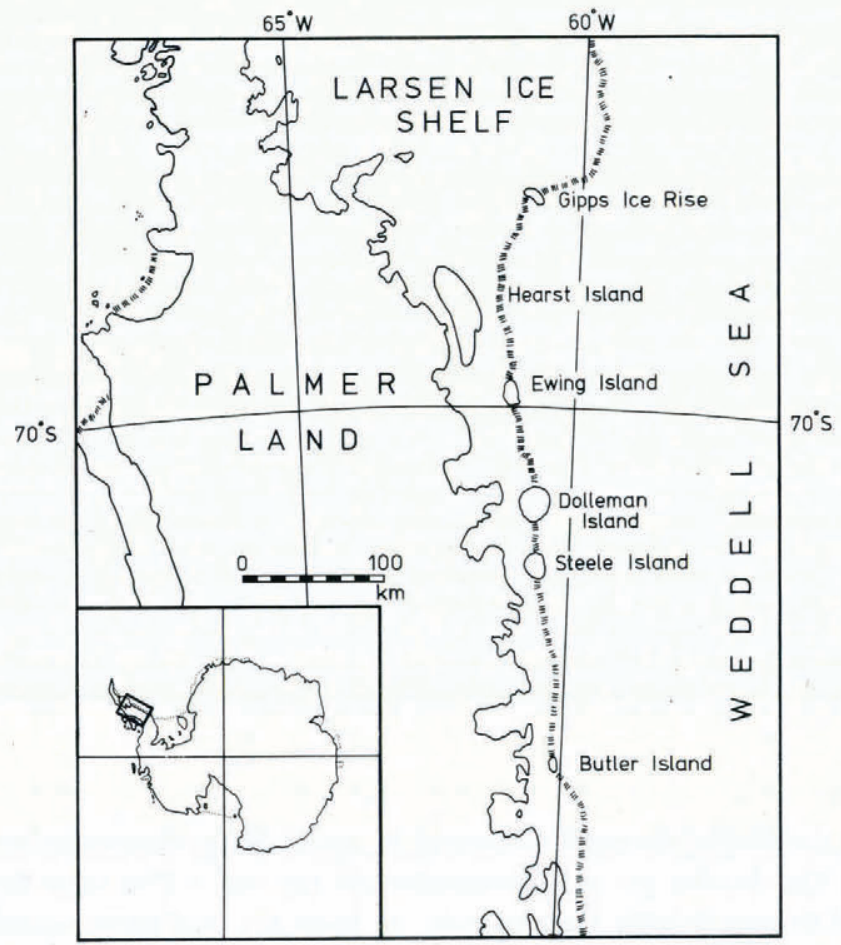

Fig. I. Map showing location of ice rises on the Antarctic Peninsula. The inset shows their position relative to Antarctica as a whole. The hatched lines represent approximate ice-shelf edges.

TABLE I. ICE-RISE DATA

\begin{tabular}{lcccccc}
\multicolumn{1}{c}{ Ice rise } & $\begin{array}{c}\text { Length } \\
\mathrm{km}\end{array}$ & $\begin{array}{c}\text { Width } \\
\mathrm{km}\end{array}$ & Ratio & $\begin{array}{c}\text { Io m } \\
\text { temperature } \\
{ }^{\circ} \mathrm{C}\end{array}$ & $\begin{array}{c}\text { Accumulation rate } \\
\mathrm{m} \mathrm{a}^{-1} \text { (ice) }\end{array}$ & $\begin{array}{c}\text { Thickness } \\
\text { at summit } \\
\mathrm{m}\end{array}$ \\
Gipps Ice Rise & 16.0 & 8.7 & 1.85 & $-\mathrm{I} 7.9$ & $0.3^{8}$ & 320 \\
Ewing Island & 14.0 & 10.4 & 1.35 & $-17.7^{*}$ & $0.30^{*}$ & 330 \\
Dolleman Island & 20.5 & 20.5 & 1.00 & -17.5 & $0.4 \mathrm{1}$ & 462 \\
Butler Island & 7.9 & 5.0 & 1.59 & -17.6 & 0.23 & 277
\end{tabular}

* These quantities are conjectural. 
These sites, situated on the east coast of the Antarctic Peninsula, have a continental climate (Martin and Peel, I 978), with $10 \mathrm{~m}$ temperatures of about $-\mathrm{I} 7.7^{\circ} \mathrm{C}$ (personal communication from D. A. Peel). Accumulation has been measured on the summit of three of the ice rises by means of annual oxygen-isotope variations in snow cores (personal communication from D. A. Peel). It lies in the region $0.2-0.4 \mathrm{~m} \mathrm{a}^{-1}$ of ice. The ice rises have been depth-sounded in previous years using airborne radio echo-equipment. These flights, made along the long axis of each island, show the bedrock to be smooth to within the resolution of the equipment (some Io m). Bedrock under Dolleman Island rises by about $100 \mathrm{~m}$ towards the summit, but under the remaining three ice rises the bedrock is horizontal to within some $20 \mathrm{~m}$. The bed shows no evidence of isostatic depression towards the centre. Ice thicknesses at the summit
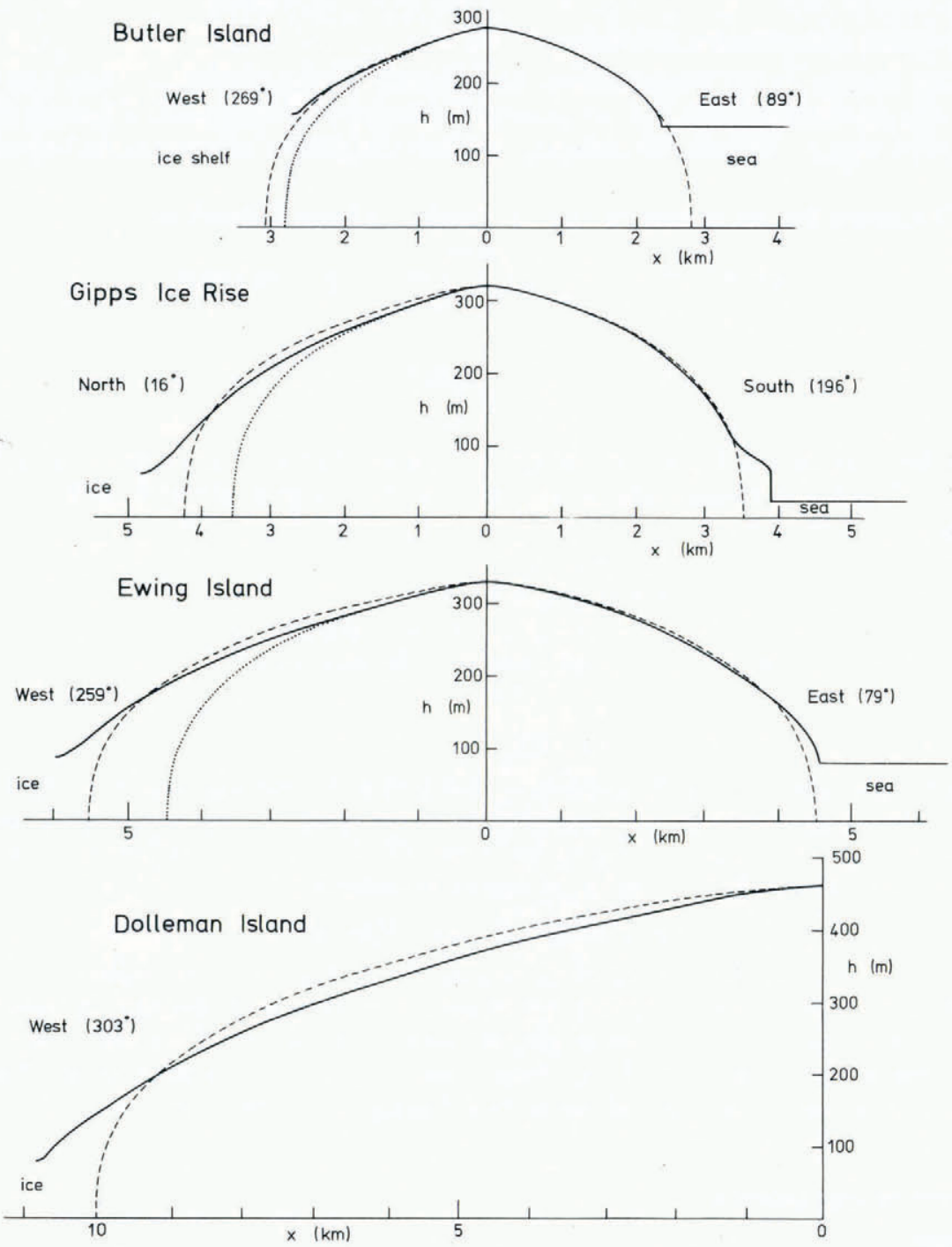

Fig. 2. Measured profiles of minor axes of four Antarctic ice rises (solid lines). Dashed lines show the best fit of Equation (II) to the profiles; dotted lines show the expected profile if the ice rises were perfectly symmetrical. Vertical scale is exaggerated by a factor of ten. 
have an expected error of about $15 \mathrm{~m}$. Table I shows Io $\mathrm{m}$ temperature, accumulation, and summit thickness for each ice rise. For Ewing Island, the temperature and accumulation rates are conjectural.

The ice rises were visited during the $1976-77$ field season in order to make accurate measurements of surface profiles. Optical levelling equipment was used, so that relative height are accurate to within a few centimetres. The measured profiles are shown by the solid lines in Figure 2; dashed and dotted lines refer to models constructed later in this paper. In addition, velocity measurements were made on the western axis of Butler Island using a line of stakes at $300 \mathrm{~m}$ intervals which was re-measured after two months by oversnow taping.

\section{TEMPERATURE AND DENSITY PROFiles}

Knowing surface snow temperatures and annual accumulation we can use estimated values for the geothermal heat flux to calculate an expected temperature profile through an ice rise (Robin, 1955). This should indicate whether the glacier is frozen to its bed or is sliding over it.

Robin's solution for temperature $T(z)$ at height $z$ above bedrock is:

with

$$
T(z)=T(h)+\frac{\sqrt{ } \pi}{2} l\left(\frac{\partial T}{\partial z}\right)_{b}[\operatorname{erf}(z / l)-\operatorname{erf}(h / l)],
$$

$$
l=\left(\frac{2 k h}{a}\right)^{\frac{1}{3}}
$$

where $h$ is the total ice thickness, $a$ is the annual accumulation, $k$ is the thermal diffusivity of ice, and $(\partial T / \partial z)_{b}$ is the basal temperature gradient due to geothermal heat flux.

Taking

$$
\begin{aligned}
h & =300 \mathrm{~m} \\
a & =0.3 \mathrm{~m} \mathrm{a}^{-1}, \\
k & =\mathrm{I} .18 \times \mathrm{Io}^{-6} \mathrm{~m}^{2} \mathrm{~s}^{-1} \text { (Robin, I 955), } \\
(\partial T / \partial z)_{b} & =0.023 \mathrm{deg} \mathrm{m}^{-1} \text { (Robin, 1955), }
\end{aligned}
$$

and

$$
T(h)=17.7^{\circ} \mathrm{C},
$$

we find that the temperature at the base is $-12.8^{\circ} \mathrm{C}$ and the average temperature is $-15.7^{\circ} \mathrm{C}$. This calculation is valid strictly only near to the centre of the ice rise where horizontal advection terms are negligible, but it serves to show that the ice rise must be frozen to its bed.

Schytt (1958) shows that density $\rho(z)$ can be modelled by

$$
\rho(z)=\rho_{\mathrm{i}}-d \exp \{-b(h-z)\}
$$

where $\rho_{\mathrm{i}}=917 \mathrm{~kg} \mathrm{~m}^{-3}$, the density of pure ice, $b=0.0258 \mathrm{~m}^{-1}$, the value used by Schytt for his observations at Maudheim, and $d$ is related to surface snow density. Measurements of density on Dolleman Island showed the density at Io $\mathrm{m}$ depth to be $580 \pm 20 \mathrm{~kg} \mathrm{~m}^{-3}$ (personal communication from D. A. Peel), which yields $d=436 \mathrm{~kg} \mathrm{~m}^{-3}$. The average density $\bar{\rho}$ through $300 \mathrm{~m}$ thickness of ice is then $860 \mathrm{~kg} \mathrm{~m}^{-3}$. This is the value we shall use.

\section{Velocity measurements}

(a) Flow law

We define strain-rates $\dot{\epsilon}_{i j}$, stresses $\sigma_{i j}(i, j=x, y, z)$, and stress deviators

$$
\sigma_{x x}{ }^{\prime}=\sigma_{x x}-\frac{1}{3}\left(\sigma_{x x}+\sigma_{y y}+\sigma_{z z}\right), \quad \text { etc. }
$$


and

$$
\sigma_{x y}^{\prime}=\sigma_{x y}, \quad \text { etc. }
$$

Then we postulate the flow law (Paterson, r969, p. 85)

$$
\dot{\epsilon}=(\tau / B)^{n},
$$

where $\dot{\epsilon}$ and $\tau$ are defined through the second invariants of the strain-rate and stress-deviator tensors,

and

$$
\left.\begin{array}{c}
2 \dot{\epsilon}^{2}=\dot{\epsilon}_{i j} \dot{\epsilon}_{i j} \\
2 \tau^{2}=\sigma_{i j^{\prime}} \sigma_{i j}^{\prime} .
\end{array}\right\}
$$

$B$ and $n$ are parameters which depend on the properties of glacier ice; $n$ reflects the mechanism of deformation, and $B$ is a factor which is dependent on temperature and density; $B$ is expected to vary with depth.

We introduce the requirement that at any point strain-rates are parallel and proportional to the corresponding stress deviators and find, using Equation (2), the flow-law formula,

$$
\dot{\epsilon}_{i j}=B^{-n} \tau^{(n-1)} \sigma_{i j}{ }^{\prime} .
$$

By analysing velocity and profile data we can determine whether Equation (4) is suitable and what are the appropria te values for $B$ and $n$.

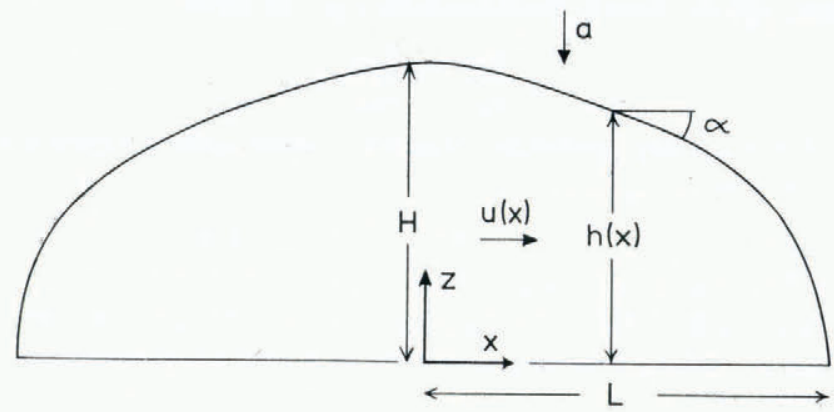

Fig. 3. Symbols used in discussion of ice rises.

\section{(b) Velocity formula}

Since the ice rise is frozen to its bed, any surface velocity is the result of shear within the ice mass. Consider a velocity $u$ in the $x$ direction, where $x$ is measured radially from the centre and $z$ is measured vertically upwards from the glacier bed (Fig. 3). We then have:

$$
\dot{\epsilon}_{x z}=\frac{1}{2}(\partial u / \partial z) \text {, }
$$

where it has been assumed that the ice deforms by simple shear. Therefore, by Equation (4),

$$
u(z)=2 \int_{0}^{z} B^{-n} \tau^{(n-1)} \sigma_{x z} \mathrm{~d} z .
$$

The term $\tau^{n-1}$ is a function of both shear and longitudinal stresses (Equation (3)). We can show that over most of the ice rise longitudinal stress deviators can be neglected. Consider the relative magnitudes of longitudinal strain-rate and shear strain-rate averaged over the thickness of the ice rise. From Equation (5) we can represent the average shear strain-rate by approximately $\frac{1}{2} u / h$ and we shall assume that longitudinal strain-rate $\dot{\epsilon}_{x x}$ is independent of depth. We need to show that $\dot{\epsilon}_{x x} \ll \frac{1}{2} u / h$. 
TABLE II. Comparison of LONGITUdinal AND SHEAR QUANTITIES

\begin{tabular}{|c|c|c|c|c|}
\hline $\begin{array}{c}\text { Distance } \\
\text { from summit } \\
\text { km }\end{array}$ & $\begin{aligned} & \dot{\epsilon}_{x x} \\
& \mathrm{~s}^{-1} \\
& \times 10^{-10}\end{aligned}$ & $\begin{array}{c}\frac{u}{2 h} \\
\mathrm{~s}^{-1} \\
\times 10^{-10}\end{array}$ & Ratio & $\begin{array}{l}\text { Ratio of } \\
\text { squares }\end{array}$ \\
\hline 0.15 & $0.8 \mathrm{I}$ & 0.45 & $0.5^{6}$ & 0.31 \\
\hline 0.45 & 0.47 & 0.73 & I. 55 & $2.4 \mathrm{I}$ \\
\hline 0.75 & 0.65 & 1.15 & I.77 & 3.13 \\
\hline 1.05 & 0.45 & 1. 48 & 3.29 & $10.8 \mathrm{I}$ \\
\hline 1.35 & $0.5^{8}$ & г. 95 & $3 \cdot 3^{6}$ & II. 32 \\
\hline 1.65 & 0.59 & 2.49 & 4.22 & $17 . \overline{8} 1$ \\
\hline 1.95 & 0.78 & 3.28 & $4.2 \mathrm{I}$ & 17.70 \\
\hline 2.25 & 1.08 & 4.53 & 4.19 & 17.59 \\
\hline 2.46 & 7.10 & 7.60 & I.07 & 1.14 \\
\hline
\end{tabular}

Direct measurements of surface velocities, and hence strain-rates were made along the western axis of Butler Island. Thickness values are available from surface-profile measurements combined with radio echo-sounding at the summit. The quantities $\dot{\epsilon}_{x x}$ and $\frac{1}{2} u / h$ are compared in Table II. It is seen that over the greater part of the ice rise (some $80 \%$ ) shear strain-rates dominate longitudinal strain-rates by a factor of between two and four. In the $400 \mathrm{~m}$ surrounding the summit, longitudinal strain-rates dominate shear strain-rates as expected (Weertman, 196r). Since, by Equation (4), we have

$$
\frac{\sigma_{x z}}{\sigma_{x x}}=\frac{\dot{\epsilon}_{x z}}{\dot{\epsilon}_{x x}}
$$

it is also true that shear stresses generally dominate longitudinal stress deviators. Now, the full expression for $\tau^{(n-1)}$ is, for $n=3$,

$$
2 \tau^{2}=\sigma_{x x^{\prime 2}}+\sigma_{y y}{ }^{\prime 2}+\sigma_{z z^{2}}{ }^{2}+2\left(\sigma_{x y^{2}}+\sigma_{x z^{2}}+\sigma_{y z}{ }^{2}\right) .
$$

Stress terms appear here squared; longitudinal stress deviator terms are therefore typically an order of magnitude smaller than shear-stress terms (Table II). We shall neglect them.

Now, the stresses $\sigma_{x y}$ and $\sigma_{x z}$ should vanish by geometrical considerations, so that we can write

and hence by Equation (6),

$$
\tau^{(n-1)} \approx \sigma_{x z}^{(n-1)},
$$

$$
u(z) \approx 2 \int_{0}^{z}\left(\frac{\sigma_{x z}}{B}\right)^{n} \mathrm{~d} z .
$$

Neglecting longitudinal stress gradients (Collins, I968) we have

$$
\sigma_{x z}=\bar{\rho} g \alpha(h-z) \text {. }
$$

Inserting this into Equation (7) and integrating, the surface velocity is found to be (Budd, 1969, p. I 18):

$$
u(h)=\frac{2}{(n+\mathrm{I})}\left(\frac{\bar{\rho} g \alpha}{B^{\prime}}\right)^{n} h^{(n+\mathrm{r})},
$$

where $B^{\prime}$ is a weighted average over depth of the variable $B$. It is

$$
B^{\prime}=\left[\frac{(n+\mathrm{I})}{h^{(n+\mathrm{I})}} \int_{0}^{h}\left(\frac{z}{B}\right)^{n} \mathrm{~d} z\right]^{-\mathrm{I} / n} .
$$

$B^{\prime}$ is heavily weighted towards the base of the glacier and it is effectively determined by the bottom $10-20 \%$ of the ice. 
(c) Comparison with measurements

Velocities on Butler Island were found to be in the range o to $8 \mathrm{~m} \mathrm{a}^{-1}$, increasing steadily away from the summit, which was assumed to be stationary.

Now from Equation (9) we have

$$
\log (u / h)=n \log (\alpha h)+C,
$$

where

$$
C=\log \left[\frac{2}{(n+\mathrm{I})}\left(\frac{\bar{\rho} g}{B^{\prime}}\right)^{n}\right] .
$$

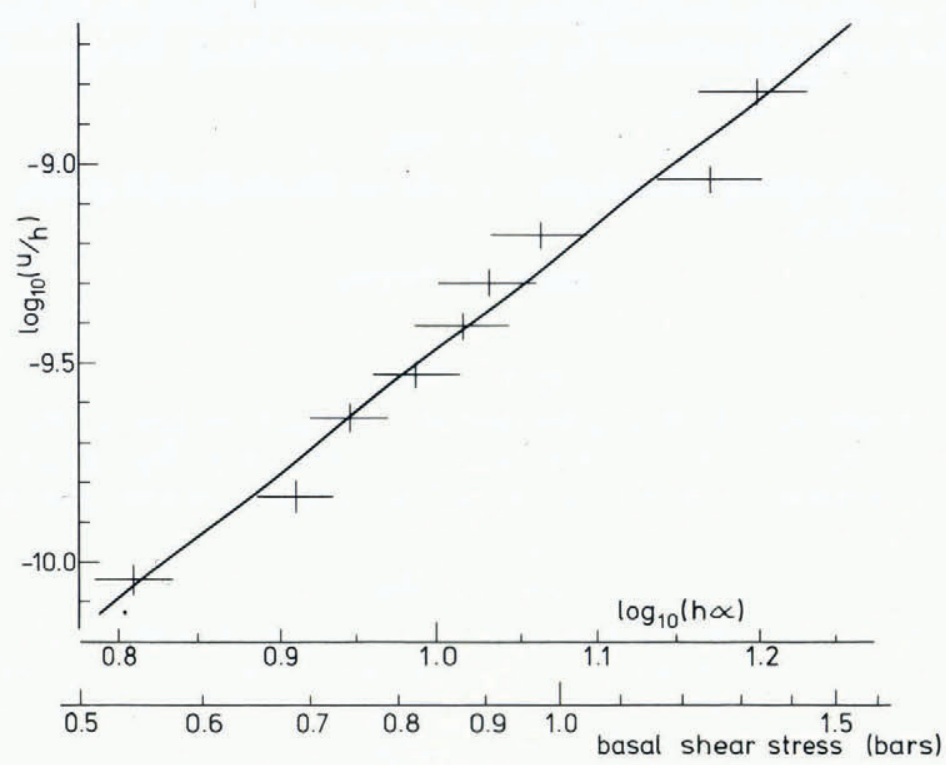

Fig. 4. Logarithmic plot of u/h against ha (Butler Island western axis). The graph gives $n=3.13 \pm 0.52$. It also shows the range of basal stress covered.

In Figure 4 the data are plotted logarithmically. The slope of the graph yields a value for $n$ and the scatter of points yields the expected error. We find that

$$
n=3.13 \pm 0.5^{2}
$$

with a linear correlation coefficient of 0.986 . The good correlation indicates that Equation (2) is an appropriate flow law and that Equation (9) is a reliable formula for velocity.

There are theoretical grounds for believing that $n$ should equal three for creep processes involving dislocation motion (Weertman, 1973[a]; Weertman, [1975]), although the theories available for dislocation velocity are unable to account for observed rates (Whitworth and others, I976; Frost and others, I976). We shall therefore assume that $n$ is exactly three. The flow parameter $B^{\prime}$ is then determined as

$$
B^{\prime}=(\mathrm{I} .0 \mathrm{I} \pm 0 . \mathrm{II}) \times 10^{8} \mathrm{~N} \mathrm{~m}^{-2} \mathrm{~s}^{\frac{1}{3}} .
$$

These observations refer to the stress range $0.5^{-\mathrm{I}} \cdot 3$ bar and a temperature of about $-\mathrm{I} 3.5^{\circ} \mathrm{C}$. The grain-size is unknown. Ice density in the lower $20 \%$ of the ice rise is, by Equation (I), about $916 \mathrm{~kg} \mathrm{~m}^{-3}$, practically that of pure ice. 


\section{EQuilibrium Profiles}

(i) Theory

Analytic expressions for the equilibrium profile of ice caps have been provided by Nye (1959) and Haefeli (I96I). Nagata (1977) has claimed that neither of these analyses satisfies the equation of mass continuity, since a moving column of ice always has a component of velocity outwards through a sloping surface, and therefore ice must be "taken off into the outer atmosphere by the ablation effect'”. We do not agree with Nagata, because a particle near the surface in an accumulation area moves downwards rather than horizontally. The ice caps considered by Nye and by Haefeli are all defined in terms of positive accumulation over their entire surface.

The condition for steady state is that the total accumulation over the catchment zone for a position $x$ should be exactly balanced by the outflow at position $x$. For a two-dimensional ice rise we have

$$
\rho_{\mathbf{i}} a x=\bar{\rho} h \bar{u},
$$

where $\bar{u}$ is the average velocity of a column at $x$, and $a$ is the accumulation rate. For an ice rise of circular plan we have

$$
\rho_{\mathrm{i}} a \pi x^{2}=\bar{\rho} h \bar{u} 2 \pi x,
$$

or

$$
\rho_{\mathrm{i}} a x=2 \bar{\rho} h \bar{u} .
$$

In general the ice rises being studied are elliptical in plan and are intermediate between these two cases. Profiles were surveyed on their minor axes, since flow lines on the major axes are more likely to be disturbed or widely divergent. Since flow lines were also unknown on the minor axis we write:

$$
\rho_{\mathrm{i}} a x=\xi \bar{\rho} h \bar{u},
$$

where $\xi$ is a factor which corrects for the geometry and is in the range $1.3-1.5$.

Now, from Equations (7) and (8), it can be shown that the average velocity of a vertical column is

$$
\bar{u}=\left(\frac{2}{n+2}\right)\left(\frac{\bar{\rho} g \alpha}{B^{\prime \prime}}\right)^{n} h^{(n+1)},
$$

where $B^{\prime \prime}$ is again a weighted average of $B$. The full expression is involved, but $B^{\prime \prime}$ is typically less than $B^{\prime}$ by approximately four per cent. It is again heavily weighted towards the bottom of the ice rise. Inserting this into Equation (Io) and writing $\alpha=\mathrm{d} h / \mathrm{d} x$ gives a simple differential equation in $h$ and $x$ having the solution

$$
\left(\frac{x}{L}\right)^{(n+1) / n}+\left(\frac{h}{H}\right)^{(2 n+2) / n}=\mathrm{I},
$$

where $H$ is the thickness of the ice rise at its summit $x=0$, and $L$ is the radius of the ice rise at bedrock level $z=0$. $L$ is given by:

$$
L=\left(\frac{n+\mathrm{I}}{2 n+2} \frac{\bar{\rho} g}{B^{\prime \prime}}\right)^{n /(n+\mathrm{I})}\left(\frac{2 \xi \bar{\rho}}{(n+2) a \rho_{\mathrm{i}}}\right)^{\mathrm{I} /(n+\mathrm{I})} H^{2} .
$$

\section{(ii) Fitting of profiles}

It is apparent from Figure 2 that Butler Island, Gipps Ice Rise, and Ewing Island show a pronounced asymmetry. Only one arm of Dolleman Island was surveyed. In each case the axis leading towards the junction with ice shelf is of longer radius than the axis leading to open water; a similar asymmetry was present on the major axis of Butler Island, the only other 
profile surveyed. The asymmetry amounts to between 5 and $15 \%$. Further, on fitting model profiles according to Equation (12) with $n=3$, it is found that in general a satisfactory fit is obtained for the axes leading to open water, while the axes leading to ice shelf show marked deviations. In Figure 2 the dashed line shows the model profile deemed to be the best fit to each axis and the dotted line shows the profile expected for the axes towards ice shelf if the ice rises were perfectly symmetrical.

Because the axes towards open water agree well with the model profiles we shall use them for calculation of the flow parameter and in the next section provide some explanation of the asymmetry of the other axes.

From Equation (13) we find, with $n=3$,

$$
B^{\prime \prime}=\frac{\bar{\rho} g}{2}\left(\frac{2 \xi \bar{\rho}}{5 a \rho_{\mathrm{i}}}\right)^{\frac{1}{3}} H^{8 / 3} L^{-4 / 3} .
$$

Applying this equation to the profile data, and taking $\xi=\mathrm{I} .5$, we find the value of the flow parameter $B^{\prime \prime}$ to be

$$
\begin{array}{ll}
\text { Butler Island: } & (\mathrm{r} .49 \pm 0.26) \times \mathrm{IO}^{8} \mathrm{~N} \mathrm{~m}^{-2} \mathrm{~s}^{\frac{1}{3}}, \\
\text { Gipps Ice Rise: } & (\mathrm{r} .35 \pm 0.24) \times \mathrm{IO}^{8} \mathrm{~N} \mathrm{~m}^{-2} \mathrm{~s}^{\frac{1}{3}}, \\
\text { Ewing Island: } & (\mathrm{I} . \mathrm{I} 6 \pm 0.2 \mathrm{I}) \times \mathrm{I}^{8} \mathrm{~N} \mathrm{~m}^{-2} \mathrm{~s}^{\frac{1}{3}},
\end{array}
$$

where the values of the radius $L$ used are the intersections of the best-fit models with the $x$ axis (Fig. 2). Data from Dolleman Island have not been used since the only axis surveyed was the one leading towards a junction with the ice shelf, which shows marked deviation from any expected profile. Combining these $B^{\prime \prime}$ values with the value of (I.OI $\left.\pm 0 . \mathrm{I} I\right) \times \mathrm{IO}^{8} \mathrm{~N} \mathrm{~m}^{-2} \mathrm{~s}^{\frac{1}{3}}$ determined from velocity data this provides a mean value of

$$
B^{\prime \prime}=(\mathrm{r} .25 \pm 0.2 \mathrm{I}) \times 10^{8} \mathrm{~N} \mathrm{~m}^{-2} \mathrm{~s}^{\hat{\jmath}},
$$

referring to a stress range of $0.5^{-1} \cdot 3$ bar and a temperature of about $-\mathrm{I} 3.5^{\circ} \mathrm{C}$. This value sits nicely on the curve published by Thomas (1973[b], fig. 2 ) of flow parameter $B$ plotted against temperature. The values of $B^{\prime}$ and $B^{\prime \prime}$ determined by the eastern profile of Butler Island and by the velocities on the western profile of Butler Island differ by $30 \%$. This may be due to differences between conditions on the two axes or to non-steady-state behaviour, but the discrepancy is not very significant. It has been pointed out (Thomas and others, I980) that the discrepancy can also be explained by allowing a decrease in $B^{\prime}$ of some $25 \%$ between the summit and the edge, due possibly to effects of recrystallization and fabric softening.

\section{Asymmetry of profile}

Weertman (1973[b]) treats three mechanisms which should lead to a shift of the ice divide away from the geometrical centre of an ice cap: non-uniform accumulation, non-uniform bedrock, and non-uniform sliding. We shall ignore the last of these since sliding does not occur. Weertman's analysis of the other factors also assumes a sliding law, so we have made the calculations afresh using Equation (13); the results are substantially the same.

Accumulation rate must vary greatly over an ice cap in order to result in any significant asymmetry. If the two axes of an ice rise are subject to two uniform but differing accumulationrates, then Equation (13) shows that these rates must differ by a factor of between two and three in order to account for the observed asymmetry. The accumulation rate must be greater on the shorter axis. It seems improbable that such a large variation could occur in the long term over a topographical feature some $10 \mathrm{~km}$ in extent and $300 \mathrm{~m}$ in height. None the less, Swithinbank (1957, p. I33) reports that on Hill "B" of Maudheim Is-Shelf (a feature of similar, though slightly greater dimensions) measurements over one year showed that accumu- 
lation varied by a factor of three across the hill, being on average greater by a factor of 1.6 on the eastern side. Accumulation-rates may therefore be responsible for the asymmetry; they would, however, also have to show gross non-uniformities over the inland arms of the ice rises to account for the marked deviation of these axes from any theoretical profile.

Secondly, Weertman proposes that there are different bedrock heights for the two axes of an ice cap. Again using Equation ( 13 ) we find that height differences of $30-50 \mathrm{~m}$ are required to account for the asymmetry. Radio echo-studies show no evidence of such differences along the major axes which were sounded, but it remains possible that such variations may occur on the minor axes.

A further explanation could be provided by variations in flow parameter $B$, but there is no reason to suppose that $B$ should vary over such a small area of study.

We shall develop here an alternative explanation involving the influence of the ice shelf on the boundary conditions at its junction with the ice rise. This accounts for the fact that the asymmetry invariably lies with the longer arm towards the ice-shelf junction.

We consider the shape of ice rise which should form on a base which has a horizontal central area but a gentle slope downwards at its edges (Fig. 5). It is unlikely that the bedrock beneath an ice rise falls off sharply at the edges, so this is a realistic assumption for the form of the bedrock. The bedrock slope is assumed to be $\theta=0$. Io rad, or $5.7^{\circ}$. It will be shown that the pressure of an ice shelf flowing against the boundary of an ice rise can cause extensive vertical strain-rates which allow the junction of the ice rise to migrate down the sloping bedrock. At the boundary with open water the ice rise terminates with the onset of the slope.

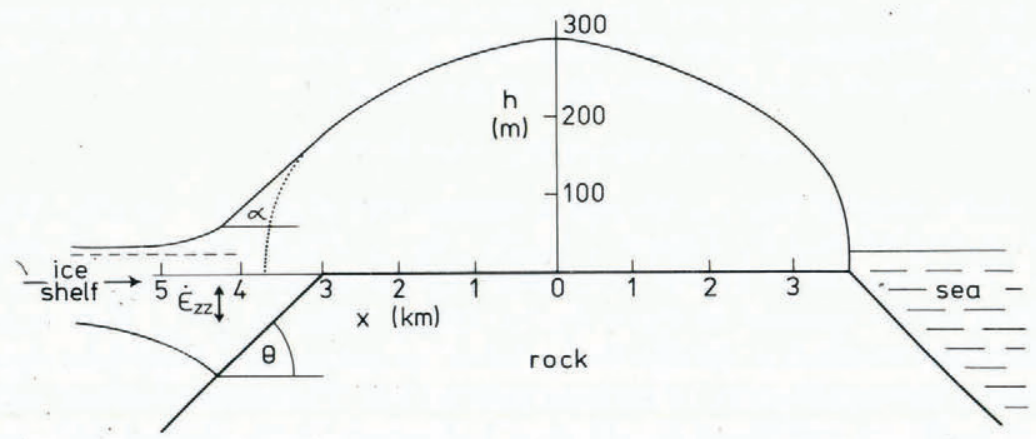

Fig. 5. Migration of grounding line down sloping bedrock, under compressive stress from an ice shelf. Vertical scale is exaggerated by a factor of ten.

Thomas and Bentley (1978) have analysed the process of advance and retreat of ice-shelf grounding lines under the influence of varying constraints. At the grounding line itself, the rate of thickening of ice shelf with time is given by the mass continuity equation

$$
\frac{\partial h}{\partial t}=\frac{\rho_{\mathrm{i}}}{\bar{\rho}}(a-m)+\bar{u}(\theta-\alpha)+h \dot{\epsilon}_{z z} .
$$

This equation expresses the rate of thickening of ice shelf at a point fixed in space as a function of accumulation-rate $a$, melt-rate $m$, horizontal advection at velocity $\bar{u}$ for surface slope $\alpha$ and bedrock slope $\theta$, and rate of thickening of a column moving in the ice shelf and having vertical strain-rate $\dot{\epsilon}_{z z} . \alpha$ and $\theta$ are negative for surfaces sloping downwards in the direction of movement. Clearly if $\partial h / \partial t$ is positive, the ice shelf is thickening and the grounding line advances; if $\partial h / \partial t$ is negative the ice shelf is thinning and the grounding line retreats. The ice shelf must advance or retreat until it finds an equilibrium point where $\partial h / \partial t=0$. There it will remain. 
In the region near the grounding line we should, strictly, include both longitudinal and shear stresses when calculating the effective stress term $\tau$ in the flow law (Weertman, 'I974). To simplify matters we shall calculate ice-shelf strain-rates neglecting shear stresses. In that case the vertical strain-rate in an ice shelf may be written (Thomas, 1973[b])

$$
\dot{\epsilon}_{z z}=-\left[\left(\frac{\mathrm{I}}{{ }_{2} \bar{B}}\right)\left\{\frac{g}{h} \int_{0}^{h} \int_{z}^{h} \rho(z) \mathrm{d} z \mathrm{~d} z-\frac{g}{2 h} \rho_{\mathrm{w}}\left(\frac{\rho_{\mathrm{i}} h}{\rho_{\mathrm{w}}}\right)^{2}-\sigma_{R}\right\}\right]^{3},
$$

where $B$ is the average of $B$ over depth, $\rho_{\mathrm{w}}$ is the density of sea-water and $\sigma_{R}$ is the total external stress acting on the ice shelf in an up-stream direction, not including water-pressure effects. For a density function of the form given in Equation (I), this can be written (Sanderson, 1979):

$$
\dot{\epsilon}_{z z}=-\left[\frac{g h}{2 \bar{B}}\left(\frac{\left(\rho_{\mathrm{i}}-\bar{\rho}\right)^{2}}{d}-\frac{\rho_{\mathrm{i}}}{2}+\bar{\rho}-\frac{\bar{\rho}^{2}}{2 \rho_{\mathrm{w}}}\right)-\frac{\sigma_{R}}{2 \bar{B}}\right]^{3} .
$$

Knowing the values of $a, m, u, \theta, \alpha$, and $h$ at the grounding line then enables us to calculate the stress $\sigma_{R}$ needed to be applied to the ice shelf in order to make the grounding line stable. This is done simply by setting $\partial h / \partial t=0$ in Equation (14) and then inserting Equation (15).

For the purposes of illustration we consider an ice rise of $300 \mathrm{~m}$ maximum thickness resting on a bed having a horizontal portion $6700 \mathrm{~m}$ long. Beyond that the bedrock dips at $5 \cdot 7^{\circ}$. Sea-level is at $25 \mathrm{~m}$ above central bedrock. We assume an accumulation rate of $0.23 \mathrm{~m} \mathrm{a}^{-1}$ and that the steady-state ideal radius is $3700 \mathrm{~m}$. The inland axis of the ice rise therefore has a sloping bed from the $3000 \mathrm{~m}$ mark onwards. In stipulating this we are introducing an asymmetry, but our purpose is to calculate the stresses necessary to sustain the asymmetry and to show that they are reasonable. By a numerical iteration process we calculate what the form of the inland arm of the ice rise is after the downward slope begins; in effect we are solving numerically the differential equation which led to Equation (12). This form is shown in Figure 5. It is seen that surface slope $\alpha$ is reduced when bedrock slope is introduced. This is because $h$ is increased and so a given velocity $\bar{u}$ can be achieved by a smaller surface slope (Equation (II)). At a distance of $4300 \mathrm{~m}$ from the ice divide, the ice is of the right depth to begin to float and so it becomes ice shelf.

Consider now the conditions at the grounding line. At $x=4300 \mathrm{~m}$ the ice thickness is I $85 \mathrm{~m}$, the surface slope is $\alpha=-0.0956$ and the velocity is $5.8 \mathrm{~m} \mathrm{a}^{-1}$. We assume the bottom melt-rate to be $1.0 \mathrm{~m} \mathrm{a}^{-1}$. Through Equation (14) this means that the ice must be subject to vertical strain-rate $\dot{\epsilon}_{z z}=1.45 \times 10^{-10} \mathrm{~s}^{-1}$ in extension in order for the grounding line to remain stationary. Equation ( ${ }^{5}$ ) then shows that a compressive stress $\sigma_{R}=1.25$ bar is required at the grounding line. This stress can easily be provided by the compressive regime as an ice shelf flows up against a stationary ice rise; stresses at the McDonald Ice Rumples were found to reach 17 bar (Thomas, I973[a]).

On the other hand, the junction on the seaward side has no such restraining force available. At the point of flotation the ice must be some $30 \mathrm{~m}$ in thickness, and sloping quite sharply. Surface slopes from the theoretical model are unreliable very near the edge, since they diverge towards infinity, so we take slopes from the observed profiles in Figure 2. A realistic surface slope is $\alpha=-0.12$ or $6.8^{\circ}$ near the edge. If the ice rise were to migrate to the sloping portion of bedrock it would require a compressive stress of $\mathrm{I} .33$ bar to prevent it from immediately beginning to retreat. No such stress is present, so it cannot migrate. Whilst on the flat portion, however, Equation (I4) shows that $\partial h / \partial t$ should be positive, and the grounding line tends to advance. This means that the grounding line is in a position of stable equilibrium at the change of slope, unable either to advance or retreat. 
This model provides a plausible explanation of the observed asymmetry. We have not attempted an accurate simulation of a particular case, since real values for $\theta, m$, and $\sigma_{R}$ are unknown. In addition, the model has used a simplified view of the combination of longitudinal and shear stress near the grounding line. It does, however, present the nature of the effect, which shows a similarity in form, though not in detail, to the profiles presented in Figure 2.

\section{The SUMmit Region}

Analyses of satellite images have indicated the presence of ridges on the summits of Antarctic ice rises (Martin, I976). However, Weertman (I96I) has proposed that the summit region of an ice cap should be flatter than predicted by a theory which considers only shear stresses, since longitudinal stresses become important. A detailed survey was made of the area surrounding the summit of Gipps Ice Rise, to discover any anomaly in behaviour. The result is shown in Figure 6 and it is compared with the theoretical profile determined for the ice rise as a whole, as in Figure 2. No significant deviation is apparent; the average error over the area covered is $30 \mathrm{~cm}$, or $0.1 \%$ of the thickness. The real profile is, if anything, slightly flatter near the summit than the theoretical profile, but the difference is comparable to the height of sastrugi. We can certainly conclude that no anomalous ridge exists.

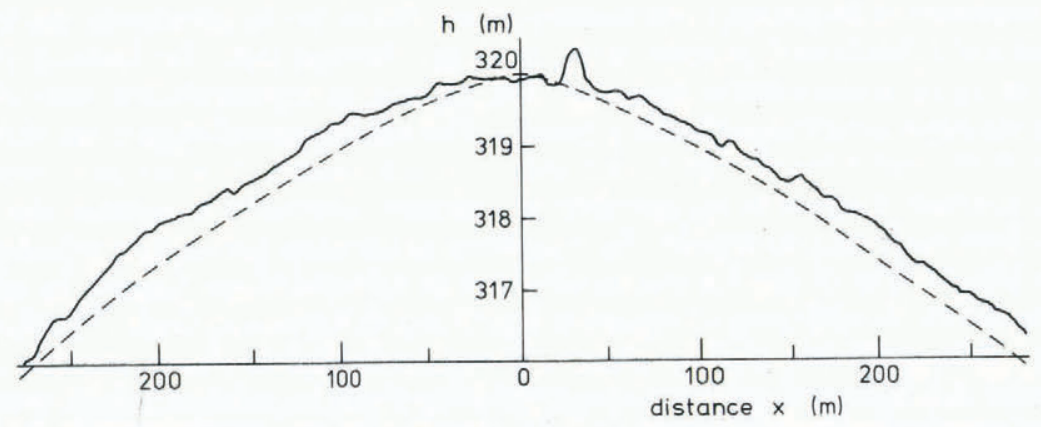

Fig. 6. Detailed summit profile of Gipps Ice Rise. The dashed line shows the theoretical profile with $L=3550 \mathrm{~m}$. Vertical scale is exaggerated by a factor of $4^{\circ}$.

The question remains, why do satellite images display apparent ridges? In a sense there is a ridge in that the surface slope changes over a relatively short distance from negative to positive, but the slopes in question are minimal. The surface slopes near the summit are of the order $0.75^{-1} .5^{\circ}$, and yet an image taken with a sun elevation of $20^{\circ}$ displays a distinct apparent shadow. We can suggest that the effect may be due to different reflective properties of superficial snow, perhaps to crystal orientation, but the relationship between satellite imagery and surface topography remains a fruitful area for investigation.

\section{Acknowledgements}

We are grateful to colleagues at the British Antarctic Survey for useful discussions, and to Dr R. H. Thomas, who introduced us to his work on grounding-line dynamics.

MS. received 9 August 1978 and in revised form 27 October 1978 


\section{R E F E R E N C E S}

Bentley, C. R., and Giovinetto, M. B. 1962. Ice-flow studies on the ice dome of Roosevelt Island, Antarctica. Transactions. American Geophysical Union, Vol. 43, No. 3, p. 369-72,

Budd, W. F. 1969. The dynamics of ice masses. ANARE Scientific Reports. Ser. A(IV). Glaciology. Publication No. 108.

Clapp, J. L. 1965. Summary and discussion of survey control for ice flow studies on Roosevelt Island, Antarctica. University of Wisconsin. Geophysical and Polar Research Center. Report 65-1.

Collins, I. F. 1968. On the use of the equilibrium equations and flow law in relating the surface and bed topography of glaciers and ice sheets. Fournal of Glaciology, Vol. 7, No. 50, p. 199-204.

Frost, H. J., and others. 1976. Kink velocities on dislocations in ice. A comment on the Whitworth, Paren, and Glen model, by H. J. Frost, D. J. Goodman, and M. F. Ashby. Philosophical Magazine, Eighth Ser., Vol. 33 , No. 6, p. $95^{\mathrm{I}-6 \mathrm{r}}$.

Haefeli, R. 196r. Contribution to the movement and the form of ice sheets in the Arctic and Antarctic. Fournal of Glaciology, Vol. 3, No. 30, p. 1 133-5I.

Kapitsa, A. P. I958. O zavisimosti formy lednikovogo kupola vostochnoy Antarktidy ot rel'yefa podlednogo lozha i kharaktera rastekaniya l'da [Relation between the shape of the ice dome of eastern Antarctica and the relief of the underlying rock and the character of ice flow]. Informatsionnyy Byulleten' Sovetskoy Antarkticheskoy Ekspeditsii, No. 1, p. $4^{\mathrm{I}-45}$.

Martin, P. J. 1976. Ridges on Antarctic ice rises. Journal of Glaciology, Vol. 1 7, No. 75, p. 141-44.

Martin, P. J., and Peel, D. A. 1978. The spatial distribution of $10 \mathrm{~m}$ temperatures in the Antarctic Peninsula. Journal of Glaciology, Vol. 20, No. 83, p. $311-17$.

Nagata, T. 1977. A theoretical steady state profile of ice sheets (two-dimensional model). Nankyoku Shiryō: Antarctic Record, No. 6o, p. 13-27.

Nye, J. F. 1959. The motion of ice sheets and glaciers. Journal of Glaciology, Vol. 3, No. 26, p. 493-507.

Paterson, W. S. B. 1969. The physics of glaciers. Oxford, etc., Pergamon Press. (The Commonwealth and International Library. Geophysics Division.)

Robin, G. de Q. 1955. Ice movement and temperature distribution in glaciers and ice sheets. Fournal of Glaciology, Vol. 2, No. 18, p. 523-32.

Sanderson, T. J. O. 1979. Equilibrium profile of ice shelves. Fournal of Glaciology, Vol. 22, No. 88, p. 435-6o.

Savel'yev, B. A. 1961. Protsessy i faktory, vliyayushchiye na formirovaniye ledyanykh kupolov-ostrovov Antarktidy [Processes and factors affecting the formation of Antarctic ice rises]. Merzlotnyye Issledovaniya (Moscow University), Vyp. 2, p. 139-46.

Schytt, V. 1958. Glaciology. II. The inner structure of the ice shelf at Maudheim as shown by core drilling. Norwegian-British-Swedish Antarctic Expedition, 1949-52. Scientific Results, Vol. 4, C.

Swithinbank, C. W. M. 1957. Glaciology. I. The regime of the ice shelf at Maudheim as shown by stake measurements. Norwegian-British-Swedish Antarctic Expedition, 1949-52. Scientific Results, Vol. 3, B.

Thomas, R. H. I $1973[\mathrm{a}]$. The creep of ice shelves: interpretation of observed behaviour. Fournal of Glaciology, Vol. 12, No. 64 , p. $55-70$.

Thomas, R. H. 1973[b]. The creep of ice shelves: theory. Journal of Glaciology, Vol. 12, No. 64, p. 45-53. Thomas, R. H., and Bentley, C. R. 1978. A model for Holocene retreat of the West Antarctic ice sheet. Quaternary
Research, Vol. 10, No. 2, p. 150-70.

Thomas, R. H., and others. 1980 . The creep of ice, geothermal heat flow, and Roosevelt Island, Antarctica, by R. H. Thomas, D. R. MacAyeal, C. R. Bentley, and J. L. Clapp. Journal of Glaciology, Vol. 25, No. 91, p. 47-60.

Weertman, J. I96i. Equilibrium profile of ice caps. Fournal of Glaciology, Vol. 3, No. 30, p. 953-64.

Weertman, J. I973[a]. Creep of ice. (In Whalley, E., and others, ed. Physics and chemistry of ice: papers presented at the Symposium on the Physics and Chemistry of Ice, held in Ottawa, Canada, I4-18 August I972. Edited by E. Whalley, S. F. Fones, L. W. Gold. Ottawa, Royal Society of Canada, p. 320-37.)

Weertman, J. 1973[b]. Position of ice divides and ice centers on ice sheets. Journal of Glaciology, Vol. 12, No. 66, p. $353-60$. Weertman, J. 1974. Stability of the junction of an ice sheet and an ice shelf. Journal of Glaciology, Vol. 13, No. 67,
p. 3-1 1.

Weertman, J. [1975.] High temperature creep produced by dislocation motion. (In Li, J. C. M., and Mukherjee, A. K., ed. Rate processes in plastic deformation of materials. Proceedings from the Fohn E. Dorn symposium. . . [Cleveland, Ohio], American Society for Metals, p. 315-36. (American Society for Metals. Materials/Metalworking Technology Series, No. 4.))

Whitworth, R. W., and others. 1976. The velocity of dislocations in ice-a theory based on proton disorder, by R. W. Whitworth, J. G. Paren, and J. W. Glen. Philosophical Magazine, Eighth Ser., Vol. 33, No. 3, p. 409-26. 